\title{
Profesyonel Futbol Takımı Seyircilerinin Bağlılık Noktalarının İncelenmesi
}

\author{
Erdinç DEMIRAY ${ }^{1 *}$, Volkan UNUTMAZ ${ }^{1}$ (D) \\ ${ }^{1}$ Ege Universitesi, Spor Bilimleri Fakültesi, İzmir.
}

Orijinal Makale

Gönderi Tarihi: 19.09.2020
Kabul Tarihi: 09.10 .2020

DOI: $10.25307 /$ jssr.797432

Online Yayın Tarihi: 31.12 .2020

\section{$\ddot{O} z$}

Bu çalışmanın amacı, profesyonel futbol takımı seyircilerinin bağlılık noktalarının incelenmesidir. Araştırmanın örneklemini yaşları 18 ile 71 arasında değişen (Yaşort=33.33, ss= $=10.79$ ), 2126 profesyonel futbol takımı seyircileri oluşturmaktadır. Trail, Robinson, Dick ve Gillentine (2003) tarafından geliştirilen, Gençer, Kiremitci, Aycan, Demiray ve Unutmaz (2012) tarafından Türkçeye uyarlanan Bağlılık Noktaları İndeksi araştırmada veri toplama aracı olarak kullanılmıştır. Elde edilen verilere, normallik testi gerçekleştirilmiş ve iç tutarlılık katsayıları hesaplanmıştır. Demografik değişkenlere göre farklılıkları belirleyebilmek üzere Mann Whitney-U ve Kruskal Wallis-H analizleri uygulanmıştır. Ölçeğin bütünü için iç tutarlık katsayısının .80 olarak hesaplandığı, alt boyutlarına ilişkin iç tutarlılık katsayılarının ise .60 ile .82 arasında değişkenlik gösterdiği belirlenmiştir. Seyircilerin kişisel bilgi formunda yer alan değişkenlere göre uygulanan karşılaştırma analizlerinde, istatistiksel olarak anlamlı $(\mathrm{p}<.05, \mathrm{p}<.01, \mathrm{p}<.001)$ farklar tespit edilmiştir. Sonuç olarak seyircilerin bağlılık noktalarının, kulüp, cinsiyet, yaş ve eğitim durumlarına göre farklılaştı̆̆ belirlenmiştir.

Anahtar kelimeler: Güdüler, Bağlılık Noktaları, Profesyonel Futbol, Seyirciler.

\section{Examining Points of Attachment of Professional Footbal Team Spectators}

\begin{abstract}
The purpose of this research was to examine points of attachment of professional football team spectators. The sample consisted of 2126 football team spectators aged between 18 and $71\left(\mathrm{X}_{\mathrm{age}}=33.33\right.$, sd= $\left.= \pm 10.79\right)$. Points of Attachment Index, consisting of 21 items, developed by Trail, Robinson, Dick and Gillentine (2003) and adapted into Turkish by Gençer, Kiremitci, Aycan, Demiray and Unutmaz (2012) was used as measurement tool. Normality test was applied and internal consistency coefficents were calculated. Mann Whitney-U and Kruskal Wallis-H analysis were used to determine group differences in terms of demographical variables. The internal consistency coefficients of the subscales were varied between .60 and .82 and, overall scale was found .80 . The findings from analysis show that there are significant differences $(p<.05$, $\mathrm{p}<.01, \mathrm{p}<.001)$ between the groups in terms of demographical variables of the spectators. In conclusion, it was determined that spectators' points of attachment may differ in terms of club, gender, age and level of education.
\end{abstract}

Keywords: Motives, Points of Attachment, Professional Football, Spectators.

\footnotetext{
* Sorumlu yazar: Dr. Öğr. Üyesi Erdinç DEMİRAY, E-posta: erdincdemiray75@ gmail.com
} 


\section{GíRiş}

Sporun günümüzde önemli bir endüstri haline dönüştüğü (Hoye, Smith, Nicholson ve Stewart, 2015:3) dil, sosyal ve dini engelleri ortadan kaldırabilmesi bakımından evrensel bir olgu olarak kabul edilmesi sebebi ile (Graham, Delpy Neirotti ve Goldblatt, 2001:3), milyarlarca tüketiciye ulaşma kapasitesine sahip olduğu bilinmektedir. Tüketiciler, kullanım ya da sahip olma amacı ile ürün ve hizmetleri satın alan birey ya da örgüt olarak tanımlanmaktadır (Schwarz ve Hunter, 2008:5). Kısa bir tanımla pazarlama, satın alma sırasındaki değişim ilişkisinin yaratılması ve devam ettirilmesidir (Kaser ve Oelkers, 2007:4). Spor pazarlaması ise, sporda tüketicilerin istek ve ihtiyaçlarının karşılanması, spor ürünleri ve hizmetlerinin pazarlanması ile diğer tüketici ve endüstriyel ürün ile hizmetlerin spor yoluyla pazarlanması olarak tanımlanmaktadır (Mullin, Hardy ve Sutton, 2014:40).

Spor pazarlamacıları için, sürdürülebilir gelirlerin arttırılmasına yönelik pazarlama stratejilerinin oluşturulması ve başarı ile uygulanması önemlidir. Çünkü bu yolla, rekabetçi bir endüstri içersinde yer almak ve örgütün varlığını sürdürebilmek mümkün olabilmektedir. $\mathrm{Bu}$ nedenle pazarlama, spor örgütlerinin genel başarısı için son derece önemli bir fonksiyon (Armstrong, Walsh ve Dees, 2019:478) olarak kabul edilmektedir. Ancak, spor pazarlamas1 oldukça karmaşık ve dinamiktir (Shank ve Lyberger, 2014:5). Dolayısı ile pazarlama dinamiklerini oluşturan olguları incelemek, araştırmacıların odaklandığı konular içerisinde yer almaktadir.

Spor endüstrisi içerisinde yer alan futbol, ulaştığı milyarlarca seyirci sayısı nedeni ile dünya genelinde en popüler spor dalı olarak (Miller ve Washington, 2016) kabul edilmektedir. Bu çerçevede tüketiciler olarak kabul edilebilecek olan seyirciler, sağladıkları dolaylı ve doğrudan gelirler (Mullin, Hardy ve Sutton, 2000) ile birlikte, takımların saha içi performanslarının arttırılmasına (Pollard ve Pollard, 2005) yönelik katkıları açısından önemli bir rol oynamaktadırlar. Bu nedenle seyircilerin, spor karşılaşmalarına katılım kararlarını etkileyen faktörleri belirleyebilmek, spor ürünleri için daha etkili pazarlama stratejilerinin oluşturulmasına büyük katkı sağlamaktadır (Woo, Trail, Kwon ve Anderson, 2009).

Sporda seyircilerin katılım kararlarını etkileyen olgular arasında gösterilen, özdeşleşme ile müsabakalara katılım kararları (Kim ve Trail, 2010) ve katılım sıklıkları arasında ilişki olduğu belirten (Mahony, Nakazawa, Funk, James ve Gladden, 2002) çalışmaların yanında, spor tüketim davranışı için önemli olduğunu belirten çalışmalar yer almaktadır (Matsuoka, Chelladurai ve Harada, 2003; Wann ve Branscombe, 1993). Ancak özdeşleşme ilgili ilk çalışmalarda odak nokta takımla özdeşleşme olurken, Trail, Anderson ve Fink (2000) sadece takımla özdeşleşmenin müsabakalara katılım kararı için yeterli olamayabileceğini belirtmişlerdir. Bu kapsamda Trail ve diğerleri (2003), seyircilerin müsabakalara katılım kararlarını etkileyen farklı faktörleri açıklamaya çalıştıkları bağlılık noktaları kavramını alan yazına sunmuşlardır.

Kwon, Trail ve Anderson (2005) bireylerin spor müsabakalarını sadece tek bir faktöre dayalı olmadan, farklı faktörler ile kurdukları güçlü sosyo-psikolojik bağlar nedeni ile seyredeceklerini ifade etmişlerdir. Buradan hareketle bu bağları, bağlılık noktaları olarak tanımlamışlardır. Öncelikle Trail ve diğerleri (2003) tarafından sunulan çok boyutlu bağlılık 
noktalarını, devamında Kwon ve diğerleri (2005) oyuncu, takım, antrenör, üniversite, toplum, spor dalı ve spor dalı düzeyi olarak isimlendirmişlerdir. Seyircilerin spor tüketimine yönelik güdüleri ile bağlılık noktaları arasındaki ilişkileri belirleyebilmek üzere de Points of Attachment Index-PAI (Bağlllık Noktaları Indeksi)'ni geliştirmişlerdir. İndeks, Trail ve diğerleri (2003) tarafından belirlenen bağlılık noktalarının yer aldığı, yedi alt boyuttan ve toplam 21 maddeden oluşmaktadır. Seyircilerin bağlılık noktalarını belirlemeye yönelik geliştirilen Bağlılık Noktaları İndeksi birçok çalışmada kullanılmış, geçerliliği ile güvenirliği farklı kültürlerde de test edilmiştir (Hallmann, Oshimi, Harada, Matsuoka ve Breuer, 2018; Robinson ve Trail, 2005; Robinson, Trail ve Kwon, 2004; Spinda, Wann ve Hardin, 2016; Trail ve diğerleri, 2003). Bu çalışmaların yanında seyircilerin spor tüketimine yönelik güdüleri ile bağlılık noktalarının cinsiyet, spor branşı seviyesi, yaş ve eğitim durumlarına göre farklılık gösterebileceği belirtilmiştir (Dietz-Uhler, Harrick, End ve Jacquemotte, 2000; Fink, Trail ve Anderson, 2002; Robinson ve diğerleri, 2004; Woo ve diğerleri, 2009). Bu bilgilerin de, spor yöneticileri ve pazarlamacıları için, demografik özelliklere göre farklı ve etkili stratejiler üretme konusunda kritik öneme sahip olduğu bildirilmektedir (Robinson ve Trail, 2005; Woo ve diğerleri, 2009).

Ülkemizde, ölçeğin Türk kültürüne ilk uyarlama çalışması Gençer, Kiremitci ve Boyacıoğlu (2011) tarafından basketbol seyircileri ile gerçekleştirilmiş, ikinci çalışma ise Gençer ve diğerleri (2012) tarafından profesyonel futbol seyircilerine uygulanmıştır. Her iki çalışmada da uygulanan Doğrulayıcı Faktör Analizi bulguları ölçeğin kabul edilebilir uyum indexlerine sahip olduğu, uygulanan iç tutarlılık hesaplamalarının ise şehir (.58) alt boyutu hariç yeterli olduğu görülmektedir. Bu kapsamda gerçekleştirilen araştırmalar ve seyircilerden elde edilen bulgularda, seyircisi oldukları kulüplere (Gençer ve diğerleri, 2012) ve cinsiyete (Gençer, 2015) göre seyircilerin bağlılık noktalarında farklılıklar tespit edilmiştir. Bağlılık Noktaları İndeksinin Türk kültürüne yönelik bir diğer uyarlama çalışması ise Gültekin Salman (2016) tarafından gerçekleştirilmiştir. Ancak ilgili çalışmada sadece takım, spor dalı ve oyuncular alt boyutlarına yer verilmiştir. Gerçekleştirilen çalışmalardan elde edilen bulgular ile alan yazına önemli katkılar sunulsa da, sayısal olarak az olduğu belirtilmektedir (Gültekin Salman, 2016). Ek olarak farklı örneklem grupları ve sayısı ile gerçekleştirilecek çalışmalar, seyircilerin özelliklerine göre daha farklı pazarlama stratejilerinin sunulmasına katkı sağlayacaktır. Bu kapsamda bu çalışmanın amacı, profesyonel futbol takımı seyircilerinin bağlılık noktalarının belirlenmesi ve demografik özelliklerine göre farklılıklarının incelenmesidir.

\section{YÖNTEM}

\section{Araştırma Modeli}

Nicel araştırma modelleri içerisinde sayılan ve varolan olguların betimlenerek açıklanması yaklaşımını kabul eden betimsel tarama modeli (Sönmez ve Alacapınar, 2017), bu çalışmada araştırma modeli olarak kullanılmıştır.

\section{Örneklem}

Çalışmanın örneklemini, amaçlı örneklem yöntemi ile seçilen ve çalışmaya gönüllü katılım sağlayan profesyonel futbol takımı seyircileri oluşturmaktadır. İlgili örnekleme yöntemi 
kullanılarak ulaşılması gereken tahmini örneklem sayısı minumum 384 yeterli iken (Yazıcıoğlu ve Erdoğan, 2007:70), yaşları 18 ila 71 arasında değişen (Ort:33,33; ss:10,79) 2126 profesyonel futbol takımı seyircisi çalışmaya katılım göstermişlerdir. Araştırmaya katılan seyircilerin detaylı demografik özellikleri Tablo 1'de sunulmuştur.

Tablo 1. Seyircilerin demografik özellikleri

\begin{tabular}{llrr}
\hline \multicolumn{1}{c}{ Değişkenler } & & $\mathbf{f}$ & \% \\
\hline \multirow{3}{*}{ Kulüp } & BJK & 1704 & 80.15 \\
& Altay & 422 & 19.85 \\
& Toplam & 2126 & 100.00 \\
\hline \multirow{3}{*}{ Cinsiyet } & Erkek & 1934 & 90.97 \\
& Kadın & 192 & 9.03 \\
& Toplam & 2126 & 100.00 \\
\hline \multirow{4}{*}{ Yaş } & $18-25$ yaş & 636 & 29.92 \\
& 26-35 yaş & 651 & 30.62 \\
& 36 ve üstü & 839 & 39.46 \\
& Toplam & 2126 & 100.00 \\
\hline \multirow{2}{*}{ Ĕgitim } & Lise ve altı & 453 & 21.31 \\
& Üniversite & 1415 & 66.56 \\
& Lisansüstü & 258 & 12.14 \\
& Toplam & 2126 & 100.00 \\
\hline
\end{tabular}

\section{Veri Toplama Araçları}

Çalışmada veri toplama araçları olarak Gençer ve diğerleri (2012) tarafından Türk kültürüne uyarlanan Bağlılık Noktaları İndeksi ve kişisel bilgi formu kullanılmıştır. Kişisel bilgi formunda kulüp, cinsiyet, yaş ile eğitim durumlarına ilişkin sorular yer almaktadır.

Bağllık Noktaları İndeksi: Bağlılık Noktaları İndeksi 7 alt boyut (oyuncular, takım, antrenör, toplum, spor, spor düzeyi, şehir) altında toplanmış, 21 maddeden oluşan bir ölçektir. Maddeler her alt boyut içinde yer alan üçer maddeden oluşmaktadır. Ters puanlanan maddelerin yer almadığı ölçüm aracı, 7'li likert (1-hiç katılmıyorum,...,7-tamamen katılıyorum) derecelendirme sistemine sahiptir. Gençer ve diğerleri (2012) tarafından Türk kültürüne uyarlanan ölçeğin elde edilen iç tutarlılık katsayıları .58 ile .92 arasında değişmekte olduğu, ölçeğin bütünü için elde edilen iç tutarlık katsayısının ise .75 olduğu belirtilmektedir.

Çalışmamızda, ölçeğin bütünü için hesaplanan iç tutarlılık katsayısı; .80'dir. Ölçeğin alt boyutlarına ilişkin katsayılarının ise, Oyuncular alt boyutu için .82, Takım alt boyutu için .71, Antrenör alt boyutu için .60, Toplum alt boyutu için .77, Spor alt boyutu için .65, Spor Düzeyi alt boyutu için .70 ve Şehir alt boyutu için .33 olarak elde edildiği görülmüştür. Nunnally (1978) hesaplanacak iç tutarlılık katsayılarının. 70 ve üzerinde, Özdamar (2002) ve Tavşancıl (2005) .60 ve üzerinde, Tuckman (1999) ise .50 ve üzerinde olmasının güvenirliliği sağlayabileceğini belirtmektedirler. Bu kapsamda ölçeğin şehir alt boyutu hariç tüm alt boyutların yeterli güvenirliği sağladığı söylenebilir. Şehir alt boyutunun önceki çalışmalarda da nispeten düşük iç tutarlık katsayılarına sahip olduğu görülmektedir (Gençer ve diğerleri, 2012; Gençer ve diğerleri, 2011). Bu nedenle ilgili çalışmada seyircilerin demografik özelliklerine göre bağlılık noktalarının karşılaştırma analizlerinde ilgili alt boyut çıkarılmıştır. 


\section{Araştırma Etiği}

Bu çalışma için, Ege Üniversitesi Sosyal ve Beşeri Bilimler Bilimsel Araştırma ve Yayın Etiği Kurulu'nun 29.07.2020 tarihli 10/10 karar sayılı (Protokol no:646) toplantısinda Etik onam alınmıştır.

\section{Verilerin Toplanması}

Çalışmanın verileri 2019-2020 futbol sezonu sonunda, sosyal medya sayfaları aracılığı ile toplanmıştır. İlgili sayfalara, çalışma için hazırlananan Google Form linki gönderilmiş ve seyirciler ile paylaşılması talep edilmiştir. Bu çerçevede hazırlanan formda, çalışmanın amacı sunulmuş, anketin herhangi bir anında çalışmadan çıkabilecekleri belirtilmiş ve katılım sağlanması talep edilmiştir. Bu kapsamda olumlu geri dönüt alınan Beşiktaş (BJK) ve Altay futbol takımı seyircileri, hazırlanan veri toplama aracında yer alan sorulara cevap vererek, çalışmaya gönüllü katılım göstermişlerdir.

\section{Verilerin Analizi}

Araştırmada elde edilen verilere öncelikle normallik testi uygulanmıştır. Bu kapsamda Kolmogorov-Smirnov değerleri incelendiğinde; ölçekte yer maddelere ilişkin verilerin normal dağılımı göstermediği görülmektedir ( $\mathrm{p}<.001$ ). Normallik analizine yönelik ikinci adım olarak verilerin basıklık ve çarpıklık değerleri incelenmiştir. Sonuçlar incelendiğinde; bazı maddelerin alan yazında basıklık ve çarpıklık için referans edilen -1.5 ile +1.5 (Tabachnick ve Fidell, 2013) ve -2 ile +2 (George ve Mallery, 2018) arasında değerler alamadığı belirlenmiştir. Son olarak basıklık ve çarpıklık için hesaplanan z değerlerinin, referans olarak belirtilen -1.96 ile $+1,96$ (Hair, Black, Babin ve Anderson, 2018) arasında yer alamadığ1 görülmüştür. Bu kapsamda gerçekleştirilen analizler sonucunda, elde edilen verilerin normal dağılım göstermedikleri belirlenmiştir. Bu nedenle karşılaştırma analizlerinde, kişisel bilgi formu ile elde edilen değişkenlerin oluşturduğu ikili gruplar için Mann Whitney-U, ikiden fazla grup için Kruskal Wallis-H analizleri uygulanmıştır. Uygulanan testler için SPSS 25.0 programından yararlanılmıştır.

\section{BULGULAR}

$\mathrm{Bu}$ bölümde, çalışmadan elde edilen verilere uygulanan istatistiksel analizler sonucunda ulaşılan bulgular yer almaktadır.

Araştırmaya katılan seyircilerin bağlılık noktalarının, kulüp değişkenine göre farklılaşıp farklılaşmadığını belirlemek üzere gerçekleştirilen Mann Whitney-U testi sonuçları Tablo 2'de izlenebilmektedir. Test bulguları incelendiğinde, ölçekten alına puanlar ile oyuncular $(\mathrm{U}=295780.0 ; \mathrm{p}<.001)$, toplum $(\mathrm{U}=82918.0 ; \mathrm{p}<.001)$ ve spor düzeyi $(\mathrm{U}=306712.5 ; \mathrm{p}<.001)$ alt boyutlarında istatistiksel olarak anlamlı farklılıklar tespit edilmiştir. Bu alt boyutların sıra ortalamaları incelendiğinde, Altay seyircilerinin BJK seyircilerine göre daha yüksek bağlılık noktalarının olduğu söylenebilir. 
Tablo 2. Kulüp değişkenine göre Mann Whitney-U analizi sonuçları

\begin{tabular}{|c|c|c|c|c|c|c|c|}
\hline Alt boyut & Değişken & $\mathbf{N}$ & Sira Ort. & Sira Top. & $\mathbf{U}$ & $\mathbf{z}$ & $\mathbf{P}$ \\
\hline \multirow{2}{*}{ Oyuncular } & BJK & 1704 & 1026.08 & 1748440.0 & \multirow{2}{*}{295780.0} & \multirow{2}{*}{-6.448} & \multirow{2}{*}{$0.000 *$} \\
\hline & Altay & 422 & 1214.60 & 512561.0 & & & \\
\hline \multirow{2}{*}{ Takım } & BJK & 1704 & 1071.88 & 1826491.5 & \multirow{2}{*}{345256.5} & \multirow{2}{*}{-1.558} & \multirow{2}{*}{0.119} \\
\hline & Altay & 422 & 1029.64 & 434509.5 & & & \\
\hline \multirow{2}{*}{ Antrenör } & BJK & 1704 & 1063.68 & 1812506.5 & \multirow{2}{*}{359241.5} & \multirow{2}{*}{-0.028} & \multirow{2}{*}{0.977} \\
\hline & Altay & 422 & 1062.78 & 448494.5 & & & \\
\hline \multirow{2}{*}{ Toplum } & BJK & 1704 & 901.16 & 1535578.0 & \multirow{2}{*}{82918.0} & \multirow{2}{*}{-24.661} & \multirow{2}{*}{$0.000 *$} \\
\hline & Altay & 422 & 1719.01 & 725423.0 & & & \\
\hline \multirow{2}{*}{ Spor Branşı } & BJK & 1704 & 1053.46 & 1795092.0 & \multirow{2}{*}{342432.0} & \multirow{2}{*}{-1.545} & \multirow{2}{*}{0.122} \\
\hline & Altay & 422 & 1104.05 & 465909.0 & & & \\
\hline \multirow{2}{*}{ Spor Düzeyi } & BJK & 1704 & 1032.50 & 1759372.5 & \multirow{2}{*}{306712.5} & \multirow{2}{*}{-4.714} & \multirow{2}{*}{$0.000 *$} \\
\hline & Altay & 422 & 1188.69 & 501628.5 & & & \\
\hline
\end{tabular}

$* \mathrm{p}<.01$

Seyircilerin cinsiyet değişkenine göre bağlılık noktaları arasındaki olası farkları belirleyebilmek üzere gerçekleştirilen Mann Whitney-U testi bulguları Tablo 3'te sunulmaktadır. Elde edilen bulgular incelendiğinde, takım ve spor düzeyi alt boyutlarında farklılık görülmemiştir ( $\mathrm{p}>.05)$. Ölçekten elde edilen puanlar ile oyuncular ( $U=149370.5$; $\mathrm{p}<.001)$, antrenör $(\mathrm{U}=158949.0 ; \mathrm{p}<.01)$, toplum $(\mathrm{U}=165164.5 ; \mathrm{p}<.05)$ ve spor branş1 $(\mathrm{U}=157297,0 ; \mathrm{p}<.01)$ alt boyutlarında ise istatistiksel olarak anlamlı farklılıklar belirlenmiştir. Oyuncular, antrenör ve toplum alt boyutlarındaki sıra ortalamaları incelendiğinde, kadın seyircilerin erkek seyircilere daha yüksek bağl1lık noktaları olduğu, spor branşı alt boyutunda ise erkek seyircilerin kadın seyircilere göre daha yüksek bağlılık noktaları olduğu görülmektedir.

Tablo 3. Cinsiyet değişkenine göre Mann Whitney-U analizi sonuçları

\begin{tabular}{|c|c|c|c|c|c|c|c|}
\hline Alt boyut & Değişken & $\mathbf{N}$ & Sira Ort. & Sira Top. & $\mathbf{U}$ & $\mathbf{z}$ & $\mathbf{p}$ \\
\hline \multirow{2}{*}{ Oyuncular } & Erkek & 1934 & 1044.73 & 2020515.5 & \multirow{2}{*}{149370.5} & \multirow{2}{*}{-5.107} & \multirow{2}{*}{$\mathbf{0 . 0 0 0} * *$} \\
\hline & Kadın & 192 & 1252.53 & 240485.5 & & & \\
\hline \multirow{2}{*}{ Takım } & Erkek & 1934 & 1070.09 & 2069547.0 & \multirow{2}{*}{172926.0} & \multirow{2}{*}{-1.933} & \multirow{2}{*}{0.053} \\
\hline & Kadın & 192 & 997.16 & 191454.0 & & & \\
\hline \multirow{2}{*}{ Antrenör } & Erkek & 1934 & 1049.69 & 2030094.0 & \multirow{2}{*}{158949.0} & \multirow{2}{*}{-3.470} & \multirow{2}{*}{$0.001 *$} \\
\hline & Kadın & 192 & 1202.64 & 230907.0 & & & \\
\hline \multirow{2}{*}{ Toplum } & Erkek & 1934 & 1052.90 & 2036309.5 & \multirow{2}{*}{165164.5} & \multirow{2}{*}{-2.543} & \multirow{2}{*}{$0.011 *$} \\
\hline & Kadın & 192 & 1170.27 & 224691.5 & & & \\
\hline \multirow{2}{*}{ Spor Branşı } & Erkek & 1934 & 1078.17 & 2085176.0 & \multirow{2}{*}{157297.0} & \multirow{2}{*}{-3.565} & \multirow{2}{*}{$0.000 * *$} \\
\hline & Kadın & 192 & 915.76 & 175825.0 & & & \\
\hline \multirow{2}{*}{ Spor Düzeyi } & Erkek & 1934 & 1056.78 & 2043818.5 & \multirow{2}{*}{172673.5} & \multirow{2}{*}{-1.613} & \multirow{2}{*}{0.107} \\
\hline & Kadın & 192 & 1131.16 & 217182.5 & & & \\
\hline
\end{tabular}

$* \mathrm{p}<.05, * * \mathrm{p}<.01$

Araştırmaya katılan seyircilerin yaş gruplarına göre bağlılık noktaları arasında olası farklılıkları belirleyebilmek üzere gerçekleştirilen Kruskall Wallis-H testi sonuçları Tablo 4'te sunulmaktadır. Gerçekleştirilen analiz sonucunda ölçeği oluşturan tüm alt boyutlarda yaş grubuna göre istatistiksel olarak anlamlı farklılıklar tespit edilmiştir. Tablo 4 incelendiğinde; oyuncular alt boyutunda 36 ve üstü yaş grubunda yer alan seyircilerin, 18-25 yaş ile 26-35 yaş gruplarında yer alan seyircilere göre daha yüksek sira ortalamalarına sahip oldukları görülmektedir $\left[\chi_{(2)}=21,947 ; \mathrm{p}<.01\right]$. Takım alt boyutunda, 36 ve üstü yaş grubunda yer alan 
seyircilerin, 18-25 yaş grubunda yer alan seyircilere göre daha yüksek sıra ortalamalarına sahip oldukları görülmektedir $\left[\chi_{(2)}=7,535 ; \mathrm{p}<.05\right]$. Diğer alt boyutlarda ise, $18-25$ yaş grubunda yer alan seyircilerin 26-35 yaş ve 36 ve üstü yaş gruplarında yer alan seyircilere göre; antrenör $\left[\chi 2_{(2)}=27,202 ; \mathrm{p}<.001\right]$, toplum $\left[\chi 2_{(2)}=43,447 ; \mathrm{p}<.001\right]$, spor branş1 $\left[\chi 2_{(2)}=12,922 ; \mathrm{p}<.01\right]$ ve spor düzeyi $\left[\chi 2_{(2)}=18,592 ; p<.001\right]$ alt boyutlarında daha yüksek sıra ortalamalarına sahip oldukları tespit edilmiştir.

Tablo 4. Yaş grup değişkenine göre Kruskal Wallis-H analizi sonuçları

\begin{tabular}{|c|c|c|c|c|c|c|c|}
\hline Alt boyut & Değişken & $\mathbf{N}$ & Sira Ort. & $\chi^{2}$ & sd & $\mathbf{p}$ & Fark \\
\hline \multirow{3}{*}{ Oyuncular } & 1) $18-25$ Yaş & 636 & 1083.61 & \multirow{3}{*}{21.947} & \multirow{3}{*}{2} & \multirow{3}{*}{0.000} & \multirow{3}{*}{$\begin{array}{l}3>1 * * * \\
3>2 * *\end{array}$} \\
\hline & 2) 26-35 Yaş & 651 & 983.00 & & & & \\
\hline & 3) 36 Yaş ve üstü & 839 & 1110.71 & & & & \\
\hline \multirow{3}{*}{ Takım } & 1) $18-25$ Yaş & 636 & 1018.38 & \multirow{3}{*}{7.535} & \multirow{3}{*}{2} & \multirow{3}{*}{0.023} & \multirow{3}{*}{$3>1 *$} \\
\hline & 2) 26-35 Yaş & 651 & 1078.04 & & & & \\
\hline & 3) 36 Yaş ve üstü & 839 & 1086.42 & & & & \\
\hline \multirow{3}{*}{ Antrenör } & 1) $18-25$ Yaş & 636 & 1162.56 & \multirow{3}{*}{27.202} & \multirow{3}{*}{2} & \multirow{3}{*}{0.000} & \multirow{3}{*}{$\begin{array}{l}1>3 * * * \\
1>2 * * *\end{array}$} \\
\hline & 2) $26-35$ Yaş & 651 & 1037.99 & & & & \\
\hline & 3) 36 Yaş ve üstü & 839 & 1008.20 & & & & \\
\hline \multirow{3}{*}{ Toplum } & 1) $18-25$ Yaş & 636 & 1191.22 & \multirow{3}{*}{43.447} & \multirow{3}{*}{2} & \multirow{3}{*}{0.000} & \multirow{3}{*}{$\begin{array}{l}1>3 * * * \\
1>2 * * *\end{array}$} \\
\hline & 2) $26-35$ Yaş & 651 & 1043.28 & & & & \\
\hline & 3) 36 Yaş ve üstü & 839 & 982.37 & & & & \\
\hline \multirow{3}{*}{ Spor Branşı } & 1) $18-25$ Yaş & 636 & 1127.41 & \multirow{3}{*}{12.922} & \multirow{3}{*}{2} & \multirow{3}{*}{0.002} & \multirow{3}{*}{$1>3 * *$} \\
\hline & 2) $26-35$ Yaş & 651 & 1065.32 & & & & \\
\hline & 3) 36 Yaş ve üstü & 839 & 1013.64 & & & & \\
\hline \multirow{3}{*}{ Spor Düzeyi } & 1) $18-25$ Yaş & 636 & 1147.32 & \multirow{3}{*}{18.592} & \multirow{3}{*}{2} & \multirow{3}{*}{0.000} & \multirow{3}{*}{$\begin{array}{l}1>3 * * * \\
1>2 * * *\end{array}$} \\
\hline & 2) $26-35$ Yaş & 651 & 1049.10 & & & & \\
\hline & 3) 36 Yaş ve üstü & 839 & 1011.13 & & & & \\
\hline
\end{tabular}

$* \mathrm{p}<.05, * * \mathrm{p}<.01, * * * \mathrm{p}<.001$

Seyircilerin bağlılık noktalarının eğitim durumu değişkenine göre bağlılık noktalarını belirleyebilmek üzere gerçekleştirilen Kruskal Wallis-H analizi bulguları Tablo 5'te yer almaktadır. Gerçekleştirilen analiz sonucunda oyuncular $\left[2_{(2)}=20.958 ; \mathrm{p}<.001\right]$, toplum $\left[\chi 2_{(2)}=12.038 ; \mathrm{p}<.01\right]$, spor branş1 $\left[\chi 2_{(2)}=47.982 ; \mathrm{p}<.001\right]$ ve spor düzeyi $\left[\chi 2_{(2)}=14.025 ; \mathrm{p}<.01\right]$ alt boyutlarında istatistiksel olarak anlamlı farkl1lıklar tespit edilmiştir. Bulgular incelendiğinde; oyuncular alt boyutunda, lise ve altı eğitim durumuna sahip seyircilerin üniversite eğitim durumuna sahip seyircilere göre daha yüksek bağlılık noktalarına sahip oldukları görülmektedir. Toplum alt boyutunda, lise ve altı eğitim durumuna sahip seyircilerin lisansüstü eğitim durumuna sahip seyircilere göre daha yüksek bağlllık noktalarına sahip oldukları görülmektedir. Spor Branşı alt boyutunda, lise ve altı eğitim durumuna sahip seyircilerin üniversite ile lisansüstü eğitim durumlarına sahip bireylere göre daha yüksek bağlılık noktalarının olduğu, ayrıca üniversite eğitim durumuna sahip seyircilerin lisansüstü eğitim durumlarına sahip bireylere göre daha yüksek bağılık noktalarına sahip oldukları belirlenmiştir. Spor düzeyi alt boyutunda ise, lise ve altı eğitim durumuna sahip seyircilerin üniversite ile lisansüstü eğitim durumlarına sahip bireylere göre daha yüksek bağlılık noktalarının olduğu görülmektedir. 
Tablo 5. Eğitim durumu değişkenine göre Kruskal Wallis-H analizi sonuçları

\begin{tabular}{|c|c|c|c|c|c|c|c|}
\hline Alt boyut & Değişken & $\mathbf{N}$ & Sira Ort. & $\chi^{2}$ & sd & $\mathbf{p}$ & Fark \\
\hline \multirow{3}{*}{ Oyuncular } & 1-Lise ve alt1 & 453 & 1156.79 & \multirow{3}{*}{20.958} & \multirow{3}{*}{2} & \multirow{3}{*}{0.000} & \multirow{3}{*}{$1>2^{* * *}$} \\
\hline & 2-Üniversite & 1415 & 1027.54 & & & & \\
\hline & 3-Lisansüstü & 258 & $\overline{1096.91}$ & & & & \\
\hline \multirow{3}{*}{ Takım } & 1-Lise ve alt1 & 453 & 1096.08 & \multirow{3}{*}{2.812} & \multirow{3}{*}{2} & \multirow{3}{*}{0.245} & \\
\hline & 2-Üniversite & 1415 & $\overline{1057.78}$ & & & & \\
\hline & 3-Lisansüstü & 258 & 1037.69 & & & & \\
\hline \multirow{3}{*}{ Antrenör } & 1-Lise ve alt1 & 453 & 1083.68 & \multirow{3}{*}{1.116} & \multirow{3}{*}{2} & \multirow{3}{*}{0.572} & \\
\hline & 2-Üniversite & 1415 & $\overline{1054.07}$ & & & & \\
\hline & 3-Lisansüstü & 258 & 1079.77 & & & & \\
\hline \multirow{3}{*}{ Toplum } & 1-Lise ve alt1 & 453 & 1134.59 & \multirow{3}{*}{12.038} & \multirow{3}{*}{2} & \multirow{3}{*}{0.002} & \multirow{3}{*}{$1>3^{* *}$} \\
\hline & 2-Üniversite & 1415 & $\overline{1057.33}$ & & & & \\
\hline & 3-Lisansüstü & 258 & 972.54 & & & & \\
\hline \multirow{3}{*}{ Spor Branşı } & 1-Lise ve alt1 & 453 & 1189.41 & \multirow{3}{*}{47.982} & \multirow{3}{*}{2} & \multirow{3}{*}{0.000} & $1>3 * * *$ \\
\hline & 2-Üniversite & 1415 & $\overline{1059.43}$ & & & & $1>2 * * *$ \\
\hline & 3-Lisansüstü & 258 & 864.74 & & & & $2>3 * * *$ \\
\hline \multirow{3}{*}{ Spor Düzeyi } & 1-Lise ve alt1 & 453 & 1145.97 & \multirow{3}{*}{14.025} & \multirow{3}{*}{2} & \multirow{3}{*}{0.001} & \multirow{3}{*}{$\begin{array}{l}1>3^{* * *} * \\
1>2^{*}\end{array}$} \\
\hline & 2-Üniversite & 1415 & 1053.04 & & & & \\
\hline & 3-Lisansüstü & 258 & $\frac{1050.04}{976.07}$ & & & & \\
\hline
\end{tabular}

$* \mathrm{p}<.05, * * \mathrm{p}<.01, * * * \mathrm{p}<.001$

\section{TARTIŞMA VE SONUÇ}

Kulüp değişkenine göre uygulanan Mann Whitney-U analizi bulgularında, alt ligde yer alan Altay seyircilerinin toplum, oyuncular ve spor düzeyi alt boyutlarında elde ettiği ortalamaların Beşiktaş seyircilerine göre daha yüksek olduğu görülmüştür. Bu bulgular Spinda ve diğerleri (2016) tarafından Amerikan futbol liginde gerçekleştirilen çalışma bulgularını destekler niteliktedir. Bu çalışmada, Altay seyircilerinin Beşiktaş seyircilerine oranla oyuncu, toplum ve spor düzeyi alt boyutunda yüksek değerler alması, seyircilerin kendi şehir takımlarına yönelik bağlılıklarının fazla, dolaylı başarı sebebi ile takımlarından gurur duymalarından kaynaklı olabilir. Nitekim Wann (2006), sosyo-psikolojik sağlık modeli çerçevesinde, seyircilerin bir takım ile özdeşmelerinin diğer bireyler ile kuracakları sosyal bağları arttırabileceğini belirtmektedir. Bu şekilde de, spor etkinliklerini seyirci olarak televizyonlardan izlemek yerine, kurdukları sosyal bağlar ve takımlarına olan coğrafik yakınlık nedeni ile müsabakalara katılımları gerçekleşebilir (Spinda ve diğerleri, 2016).

Cinsiyet değişkenine yönelik uygulanan Mann Whitney-U analizi bulgularında, kadın seyircilerin oyuncular, antrenör ve toplum alt boyutlarında erkek seyircilere göre daha yüksek bağl1lıkları olduğu görülmüştür. Spor dalı alt boyutunda ise, erkek seyircilerin kadın seyircilere göre daha yüksek bağlılıkları olduğu belirlenmiştir. Bu sonuçlar bazı alt boyutlar açısından Robinson ve Trail (2005) tarafından gerçekleştirilen araştırma bulgularını desteklemekte, ancak Gençer (2015) ve Tokmak ve Aksoy (2016) tarafından gerçekleştirilen çalışma sonuçları ile çelişmektedir. Gençer (2015) profesyonel futbol takımı seyircileri ile gerçekleştirdiği çalışmada, cinsiyete göre istatistiksel olarak anlamlı farklılık bulunmazken, Tokmak ve Aksoy (2016) çalışmasında, oyuncular ve takım alt boyutlarında erkekler lehine anlamlı farklılıklar görülmektedir. $\mathrm{Bu}$ çalışmada elde edilen sonuçlar ise, ilgili araştırmalardan elde edilen bulgulardan farklılıklar göstermektedir. Robinson ve Trail (2005) gerçekleştirdiği çalışmada 
ise; oyuncular alt boyutunda kadın seyircilerin erkek seyircilere göre daha yüksek bağl1lıklarının olduğu, spor dalı alt boyutunda ise erkek seyircilerin kadın seyircilere göre daha yüksek bağl1lıklarının olduğu görülmektedir. Yine benzer şekilde, Tokmak ve Aksoy (2016) bulgularında, erkek seyircilerin spor dalı alt boyutunda kadın seyircilere göre daha yüksek bağlılıklarının olduğu görülmektedir. Bu çalışmadan elde edilen bulgular da her iki çalışma bulgularını destekler niteliktedir. Bu kapsamda kadınların profesyonel futbol müsabakalarına katılımları sırasında, spor dalının kendisinden çok, farklı olgulardan etkilenmiş olabileceği söylenebilir.

Seyircilerin yaş gruplarına göre gerçekleştirilen analizler incelendiğinde; yaşları 18-25 aralığında bulunan seyircilerin daha üst yaş gruplarından gelen seyircilere göre; antrenör, toplum, spor dalı ve spor düzeyi alt boyutlarında daha yüksek bağlılığa sahip oldukları görülmektedir. Oyuncu ve takım alt boyutlarında ise, 36 yaş ve üstünde yeralan seyircilerin, diğer yaşlarda yer alan seyircilere göre daha yüksek bağlılığa sahip oldukları görülmektedir. $\mathrm{Bu}$ çerçevede yaşa göre elde edilen farkl1lıklar, Robinson ve diğerleri (2004) tarafından golf seyircileri üzerine gerçekleştirilen çalışmayı destekler niteliktedir. İlgili çalışmada, profesyonel golf turnalarını izlemek üzere gelen seyircilerin bağlılık noktaları ile yaşları arasındaki ilişki olduğu belirtilmektedir. Gültekin Salman (2016) tarafından gerçekleştirilen çalışmada ise, yaş gruplarına göre oyuncular alt boyutunda farklılık bulunduğu belirtilmiştir. Bu kapsamda elde edilen bulgular sonucunda, düşük yaş grubunda bulunan seyircilerin büyük yaş gruplarında yer alan seyircilere göre daha yüksek bağlılığa sahip oldukları söylenebilir.

Eğitim durum değişkenine göre uygulanan Kuruskall-Wallis bulgularında oyuncular, toplum, spor dalı ve spor düzeyi değişkenlerinde istatistiksel olarak anlamlı gruplararası farkl1lıkların bulunduğu belirlenmiştir. Bu çerçevede elde edilen sonuçlarda, lise mezunu ve altında eğitim durumuna sahip seyircilerin, daha üst eğitim durumlarına sahip seyircilere göre daha yüksek sıra ortalamalarına sahip olduğu görülmektedir. Bu sonuçlar Gültekin Salman (2016) tarafından gerçekleştirilen çalışma bulgularını destekler niteliktedir. İlgili çalışmanın sonuçlarına bakıldığında, lise mezunu taraftarların bağlılık noktalarının, üniversite ve lisansüstü eğitim durumuna sahip bireylere göre daha yüksek olduğu görülmektedir.

Sonuç olarak, spor yöneticileri ve pazarlamacıları için seyircilerin bağlılık noktalarının bilinmesi, spor pazarlaması açısından önemli bir konudur. Bu çerçevede gerçekleştirilen çalışma bulguları, seyircilerdeki bağlılık noktalarının kulüp, cinsiyet, yaş ve eğitim durumları açısından farklılıklar gösterdiğini ortaya koymaktadır. Spor yöneticilerinin ve pazarlamacılarının, seyircilerinin ilgili ya da başka çalışmalar ile ortaya konabilecek farklılıklarına göre pazarlama stratejileri oluşturmaları, rekabetçi çevrede spor örgütlerinin devamlılı̆̆ını sağlayabilecektir.

\section{ÖNERILER}

Seyircilerin bağlılık noktalarının incelenmesine yönelik çalışmalarda, cinsiyete yönelik karşılaştırmalar için daha kapsamlı çalışmalar gerçekleştirilebilir. Yine, farklı spor dallarının ve düzeylerinin yer aldığı örneklemler üzerinde gerçekleştirilecek çalışmalar, seyircilerin özelliklerine göre oluşturulacak pazarlama stratejileri için önemli katkılar sağlayacaktır. Ayrıca bağlılık noktalarından biri olarak bildirilen şehir alt boyutunun tekrar gözden geçirilerek, yeni ve farklı ifadeler ile bir araya getirilerek güvenirlik analizlerinin tekrarlanması önerilmektedir. 


\section{KAYNAKLAR}

Armstrong, K. L., Walsh, P. \& Dees, W. (2019). Sport marketing. In P. M. Pedersen \& L. Thibault (Eds.), Contemporary sport management (6th. ed.). Champaign, IL: Human Kinetics, Incorporated.

Dietz-Uhler, B., Harrick, E. A., End, C. \& Jacquemotte, L. (2000). Sex differences in sport fan behavior and reasons for being a sport fan. Journal of Sport Behavior, 23(3), 219-231.

Fink, J. S., Trail, G. T. \& Anderson, D. (2002). Environmental factors associated with spectator attendance and sport consumption behavior: Gender and team differences. Sport Marketing Quarterly, 11(1), 8-19.

Gençer, R. T. (2015). Spectator motives and points of attachment: Gender differences in professional football. The Anthropologist, 19(1), 77-85. doi:10.1080/09720073.2015.11891641.

Gençer, R. T., Kiremitci, O., Aycan, A., Demiray, E. ve Unutmaz, V. (2012). Profesyonel futbol takımı seyircilerinin spor tüketimine yönelik güdüleri ve bağlılık noktaları arasındaki İlişki. Ege Akademik Bakış, 12(Özel Sayı), 41-53.

Gençer, R. T., Kiremitci, O. \& Boyacıŏlu, H. (2011). Spectator motives and points of attachment: An investigation on professional basketball. Journal of Human Kinetics, 30(1), 189-196.

George, D. \& Mallery, P. (2018). IBM SPSS statistics 25 step by step: A simple guide and reference (15th. ed.). New York: Routledge.

Graham, S., Delpy Neirotti, L. \& Goldblatt, J. J. (2001). The ultimate guide to sports marketing (2nd. ed.). New York: McGraw-Hill.

Gültekin Salman, G. (2016). Türk futbol taraftarların bağlantı noktalarının İncelenmesi ve ölçek güvenirliliğinin test edilmesi. İstanbul Aydın Üniversitesi Dergisi, 8(29), 101-142.

Hair, J. F., Black, W. C., Babin, B. J. \& Anderson, R. E. (2018). Multivariate data analysis (8th. ed.). China: Cengage Learning EMEA.

Hallmann, K., Oshimi, D., Harada, M., Matsuoka, H. \& Breuer, C. (2018). Spectators' points of attachment and their influence on behavioural intentions of women's national football games. Soccer \& Society, 19(7), 903-923. doi:10.1080/14660970.2016.1267634.

Hoye, R., Smith, A. C. T., Nicholson, M. \& Stewart, B. (2015). Sport management: Principles and applications (4th. ed.). New York: Routledge.

Kaser, K. \& Oelkers, D. B. (2007). Sports and entertainment marketing (3rd. ed.). USA: Thomson Higher Education.

Kim, Y. K. \& Trail, G. T. (2010). Constraints and motivators: A new model to explain sport consumer behavior. Journal of Sport Management, 24(2), 190-210.

Kwon, H. H., Trail, G. T. \& Anderson, D. (2005). Are multiple points of attachment necessary to predict cognitive, affective, conative, or behavioral loyalty? Sport Management Review, 8(3), 255-270. doi:https://doi.org/10.1016/S1441-3523(05)70041-3.

Mahony, D. F., Nakazawa, M., Funk, D. C., James, J. D. \& Gladden, J. M. (2002). Motivational factors influencing the behaviour of j. League spectators. Sport Management Review, 5(1), 1-24. doi:https://doi.org/10.1016/S1441-3523(02)70059-4.

Matsuoka, H., Chelladurai, P. \& Harada, M. (2003). Direct and interaction effects of team identification and satisfaction on intention to attend games. Sport Marketing Quarterly, 12(4), 244-253.

Miller, R. K. \& Washington, K. (2016). Sports marketing 2016-2017 (17th. ed.): Richard K Miller \& Assoc.

Mullin, B. J., Hardy, S. \& Sutton, W. (2000). Sport marketing (2nd. ed.). USA: Human Kinetics.

Mullin, B. J., Hardy, S. \& Sutton, W. (2014). Sport marketing (4th. ed.). USA: Human Kinetics.

Nunnally, J. C. (1978). Psychometric theory. New York, NY: McGraw-Hill. 
Özdamar, K. (2002). Paket programlar ile istatistiksel veri analizi (4. bask1). Eskişehir: Kaan Kitabevi.

Pollard, R. \& Pollard, G. (2005). Long-term trends in home advantage in professional team sports in north america and england (1876-2003). Journal of Sports Sciences, 23, 337-350. doi:10.1080/02640410400021559.

Robinson, M. J. \& Trail, G. T. (2005). Relationships among spectator gender, motives, points of attachment, and sport preference. Journal of Sport Management, 19(1), 58-80. doi:DOI 10.1123/jsm.19.1.58.

Robinson, M. J., Trail, G. T. \& Kwon, H. (2004). Motives and points of attachment of professional golf spectators. Sport Management Review, 7(2), 167-192. doi:https://doi.org/10.1016/S1441-3523(04)70049-2.

Schwarz, E. \& Hunter, J. (2008). Advanced theory and practice in sport marketing. Hungary: ButterworthHeinemann.

Shank, M. D. \& Lyberger, M. R. (2014). Sports marketing: A strategic perspective (5th. ed.). New York: Routledge.

Sönmez, V. \& Alacapınar, F. G. (2017). Örneklendirilmiş bilimsel araştırma yöntemleri (5. bask1). Ankara: Anı Yayıncilik.

Spinda, J. S. W., Wann, D. L. \& Hardin, R. (2016). Attachment to sports conferences: An expanded model of points of attachment among professional, collegiate, and high school football fans. Communication \& Sport, 4(3), 347-362. doi:10.1177/2167479515578262.

Tabachnick, B. G. \& Fidell, L. S. (2013). Using multivariate statistics (6th. ed.). USA: Pearson Education.

Tavşancıl, E. (2005). Tutumların ölçülmesi ve spss ile veri analizi. Ankara: Nobel Yayın Dağıtım.

Tokmak, G. \& Aksoy, R. (2016). Points of attachment on football clubs: An application on "the big four" supporters in turkish super league. Sport \& Society/Sport si Societate, 16(2), 25-36.

Trail, G. T., Anderson, D. \& Fink, J. S. (2000). A theoretical model of sport spectator consumption behavior. International journal of sport management, 1(3), 154-180.

Trail, G. T., Robinson, M. J., Dick, R. J. \& Gillentine, A. J. (2003). Motives and points of attachment: Fans versus spectators in intercollegiate athletics. Sport Marketing Quarterly, 12(4), 217-227.

Tuckman, B. (1999). Conducting educational research (5th. ed.). Orlando: Harcourt Brace.

Wann, D. L. (2006). Understanding the positive social psychological benefits of sport team identification: The team identification-social psychological health model. Group Dynamics: Theory, Research, and Practice, 10(4), 272-296. doi:10.1037/1089-2699.10.4.272.

Wann, D. L. \& Branscombe, N. R. (1993). Sports fans: Measuring degree of identification with their team. International Journal of Sport Psychology, 24(1), 1-17.

Woo, B., Trail, G. T., Kwon, H. H. \& Anderson, D. F. (2009). Testing models of motives and points of attachment. Sport Marketing Quarterly, 18(1), 38-53.

Yazıcıoğlu, Y. ve Erdoğan, S. (2007). SPSS uygulamalı bilimsel araştırma yöntemleri (2. baskı). Ankara: Detay Yayıncilik.

Bu eser Creative Commons Atıf-GayriTicari 4.0 Uluslararası Lisansı ile lisanslanmıştır. 